\title{
Human Right, PSK And Justice In Law
}

\author{
${ }^{1}$ Nynda Fatmawati Octarina, ${ }^{2}$ Muh. Barid Nizarudin Wajdi \\ ${ }^{1}$ Narotama University \\ ${ }^{2}$ STAI Miftahul Ula Nganjuk
}

\section{baridnizar84@gmail.com}

\begin{abstract}
Human rights is an international issue and a highly prominent source of conversation in the current decade. This requires serious attention for its enormous dimensions of its influence in international and national life. The state of Indonesia as a state of law (rechtstaat) also needs to be understood higher attention to human rights. Therefore, that in reform era, a big agenda requires a change of life order in nation and state. One of the most notable changes is the protection of citizen rights related to Human Rights itself. Journalist as journalistic perpetrator can be categorized as a witness or victim if the condition fulfills the requirement as witness or victim as mentioned in Law of Witness and Victim Protection, Criminal Code. Victim means journalist is suffering from physical, mental, and/or economic loss caused by criminal act and as a witness if the reporter hears on his own behalf and personally experiences a criminal act. As a witness and victim, journalist is also entitled to the protection of the law granted by the state as in Witness and Victim Protection Act. These rights ensure safety and security of witnesses and victims to assist smoothness in a criminal proceeding process.
\end{abstract}

Keyword : Human right, Justice, law, PSK

\section{INTRODUCTION}

Human rights is an international issue and a highly prominent source of conversation in the current decade. This requires serious attention for its enormous dimensions of its influence in international and national life. The state of Indonesia as a state of law (rechtstaat) also needs to be understood higher attention to human rights. Therefore, that in reform era, a big agenda requires a 
change of life order in nation and state. One of the most notable changes is the protection of citizen rights related to Human Rights itself.

Constitution of 1945 of the State of the Republic of Indonesia determines that Indonesia is a state based on law not based merely on power (rechstaat). As a consequence of such provision, one of the principles of the rule of law is equality before the law for protection of human rights and free and independent judiciary. Therefore everyone is entitled to fair recognition, assurance and legal certainty, as well as equal recognition before the law.

Law determines what to do and what is forbidden. The intended targets of law are not only those who manifestly violate law but also legal act and tools of the state to act according to the law. Such legal system is a form of law enforcement.

The 1945 Constitution of the Fourth Amendment article 27 (1) states:

"All citizens shall be equal before the law and the government and shall be required to respect the law and the government, with no exceptions.."

And article 28D (1) mentions:

"Every person shall have the right of recognition, guarantees, protection and certainty before a just law, and of equal treatment before the law."

The definition of legal protection is distinguished into two: preventive legal protection and repressive legal protection ${ }^{1}$. On preventive legal protection, people are given opportunity to file their objections or opinions before a government decision becomes definitive. Preventive legal protection aims to prevent the occurrence of a dispute while repressive legal protection aims to resolve in the event of a dispute.

\footnotetext{
${ }^{1}$ Philipus M. Hadjon, Perlindungan Hukum Bagi Rakyat Indonesia, Bina Ilmu, Su rabaya, 1987, p. 2
} 
Preventive legal protection is especially meaningful for governmental action based on freedom of action as with this protection government is encouraged to be cautious in making decisions based on discretion².

Repressive legal protection is generally performed through judicial institutions. In Indonesia today there are various bodies that partially handle legal protection for the people. Rochmat Soemitro groups them into three:
A. Courts within General Courts
B. Government agencies as administrative appeals agencies
C. Special agencies ${ }^{3}$.

These judicial bodies are established in order to provide legal protection to every citizen as mandated in the 1945 Constitution. This also applies to citizens working in the field of journalism. Journalistic activity actually has long been known in the world. Journalistic activity is always present in the midst of society, in line with the dynamic social activities of his life, especially in modern society today.

We know Greeks from human civilization history. Thousand years before Christ, they used torch flame as a gesture that can be seen from far away. Indians used the smoke to send information to his colleagues far from them. People picked a piece of wood to sound when it is hit, and the sound could be heard from afar. The tool is also used to notify an event or convey information that needs to be paid attention by all or a group of people. All of these are all manifested in a process between relationships among members of the group concerned. In the inter-relationship, an exchange of opinion or experience with each other occurred as socialization process. The process occurs due to interaction between humans themselves as the nature of absolute social. As a

\footnotetext{
${ }^{2}$ F.H. van der Burg, Rechtsbescherming tegen de Overheid, serie, Staats -en Bestuurs recht 1, Nijmegen, 1983, p. 187

${ }^{3}$ Roch mat Soemitro, Masalah Peradilan Administrasi Dalam Hukum Pajak di Indonesia, Eresco, Bandung, 1976, p. 44
} 
social creature (zoon politicon) people always want to know about other people or environment, and always wanted to tell all things happened to his friends.

With interaction activities, humans convey messages in the form of thoughts, ideas, or other statements that can affect other humans for a particular purpose. In accordance with the development of aptitude for learning, the message of is no longer in the form of speech but also uses other symbols expressed in the form of writing, drawing, gestures, motion, song, and so on.

Sometimes some types of statements are combined into a single message packet according to the purpose of the sender whether the purpose for clearance, education, indoctrination, propaganda, public relations, publicity, and so forth. If the message is intended to provide news about activities and or events that occur every day, to public, the processing of the messages is called journalism ${ }^{4}$. Meanwhile the delivery of the message to public is known as communication process. The term communication comes from Latin, communicare, which means 'to tell' or 'participate'. A person who makes communication is called communicators.

Every event, fact, and or data that exists in this universe always attracts the interest of communicator who is the man himself. As humans are social beings (zoon politicians) who always want to know everything that is around and wants to convey all contents of their heart or mind, all reality that surrounds or there is a relationship with his interests, is always a concern.

Various definitions of journalism are indicated by opinions of experts; it is art and skills of searching, collecting, processing, composing, and presenting news about events that occur every day beautifully, in order to meet all the needs of the conscience of the audience, changes in attitudes, opinions, and behavior of the audience in accordance with the will of the journalists ${ }^{5}$. Astrid

\footnotetext{
${ }^{4}$ Kustadi Suhandang, Pengantar Jurnalistik Seputar Organisasi, Produk \& Kode Etik, Nuansa, Bandung, 2010, .p. 15

5 Ibid, h. 21
} 
Susanto also provides journalistic definition as an occurrence of recording and/or reporting and dissemination of daily activities ${ }^{6}$.

From some of the above definition, journalism as an activity of research, processing and delivery of news conducted by a so-called Journalist. Indonesia has possessed positive law regarding to journalism Law Number 40 Year 1999 (State Gazette of the Republic of Indonesia Year 1999 Number 166, Supplement to State Gazette of the Republic of Indonesia Number 3887) on Press.

These laws are established to regulate activities of the press in Indonesia in a binding legal provision to create a healthy atmosphere and support for journalists and other press people in carrying out their activities.

As mandated in Article 28 of the 1945 Constitution guarantees freedom of association and assembly, issuing thoughts in spoken and written form. The press which includes printed media, electronic media and other media is one means to issue thoughts with the spoken and written form. To function optimally as mandated by Article 28 of the 1945 Constitution, it is necessary for press to establish Law on Press. Maximum function is necessary as the independence of press is a form of people's sovereignty and and is important element in society, nation and democratic state.

Article 1 of Law no. 40 Year 1999 on Press (hereinafter referred to as Press Law), mentioned the meaning of the press as follows:

"Press is a social institution and a medium of mass communication that carries out journalistic activities including seeking, obtaining, possessing, storing, processing, and conveying information in writing, voice, images, sound and graphics as well as data and graphics or in other forms using media print, electronic media, and all kinds of channels available."

\footnotetext{
${ }^{6}$ Astrid S. Susanto, Komunikasi Massa, Bina Cipta, Bandung, 1986, p. 73
} 
The notion of journalists is also mentioned in Article 1 of Law no. 40 Year 1999 About Press as follows:

"Journalists are people who regularly carry out journalistic ac tivities." Journalists are human beings who must be able to search, process, and create the content of their journalistic products by using a certain spirit. Today journalists are always faced with great challenges more than just finding and collecting facts of events but also the need of professionalism, both with the techniques of communication and the field of knowledge associated with the event.

In a democratic world today journalism is very necessary and important, as everyone will not be able to organize or do something without obtaining information first. linformation about what is and is happening in the universe, whether related to political, economic, socio-cultural, security, and other issues, can be obtained by enjoying journalistic products such as content of newspapers, broadcast Radio and television.

Press plays an important role. Press that has the independence to seek and convey information also needs to realize human rights guaranteed by Act, one of which is the 19th Charter of the United Nations Human Rights Article states: "Everyone shall have the right to freedom of expression; In this right include freedom of opinion without interference, and to seek, receive, and impart information and ideas through any media and regardless of territorial boundaries. "

This proves that Press including the work of journalists is highly respected and protected as one part of Human Rights. Press also exercises social control to prevent abuse of power of corruption, collusion, nepotism, and other irregularities. In carrying out duties, journalists sometimes experience obstacles. Frequentlythey are confronted with those who do not like their report. Constraints and obstacles will certainly greatly affect the performance of a 
journalist. Sometimes reporters also know about crime or unlawful act both criminal and civil.

In everyday life people are frequently confronted with urgent need, a need for complacency and sometimes even out of desire or insistence on maintaining self-status. In general, the needs of every human being can be met, though not entirely, in circumstances that do not require insistence from within or from others.

Fulfillment of need is sometimes not balanced with careful thought which may harm environment or other human beings. The negatif impact is not balanced with atmosphere and life of good value. This is frequently found and informed to the public by journalists.

Journalist may become a witness or victim of an unlawful act particularly in a criminal act. A criminal act is an act prohibited by a rule of law, a prohibition of which is accompanied by a threat (sanction) in the form of a specific penalty for whoever violates the prohibition ${ }^{7}$. Basically the punishment given to a criminal act in concrete has two purposes:

1. To frighten everyone not to do bad deeds.

2. To educate people who have done bad deeds to be good and acceptable in the life of their environment ${ }^{8}$.

In the process of law enforcement, the role of witnesses is highly needed. The role of a witness in every criminal case is important as witness statements can influence and determine the tendency of judge decisions. A witness is deemed to have capability of investigation, prosecution until trial in court that court can proceed transparently, independently and fairly.

However, in the practice of a criminal case a person who is faced in a hearing is the only witness. Meanwhile in criminal justice principle of unus testis

\footnotetext{
${ }^{7}$ Moeljatno, Azaz-Azaz Hukum Pidana, Bina Aksara, Jakarta, 1987, p. 54

${ }^{8}$ Ibid, p. 157
} 
nulus testis applies, which means one witness is not a witness if not supported by other evidence. Judge's verdict can be freedom in this case.

The position of witnesses in criminal justice process occupies a key position, as seen in Article 184 of Criminal Procedure Code. As the main evidence, the absence of witness is crucial. The importance of witness status in criminal justice process has been started since the beginning of criminal justice process. Unfoldin of lawlessness cases is largely based on information from public.

Similarly, in the following process, at the prosecutor's office to court, witness's testimony as the main evidence becomes the judge's reference in deciding whether or not a defendant is guilty. Thus, it is clear that witnesses have a big contribution in enforcing law and justice ${ }^{9}$.

Witness is one of important factors in proofing or disclosure of facts to be used as reference in finding other evidence to corroborate an investigation, and even proof in court. The importance of the role of witness in the process of law enforcement, especially the criminal law brings consequences for witness, both the victim witness and the reporting witnesses and other witnesses in proofing perpetrators of the crime.

In the field of criminal law, its enforcement is not as especially in obtaining witness statements. It is evident that there are still many victims of crime, such as cases of domestic violence, crimes against children, crimes against women and other crimes where witnesses are reluctant and even the victim is afraid to report the crimes committed against her.

In the field of criminal procedural law, witness is one of the few valid evidences. Based on Article 184 (1) of Law no. 8 year 1981 (State Gazette of the Republic of Indonesia of 1981 Number 76, Supplement to the State Gazette of the

\footnotetext{
${ }^{9}$ Surastini Fitriasih, "Perlindungan Saksi Dan Korban Sebagai Sarana Menuju Proses Peradilan (Pidana) Yang Jujur Dan Adil ”, http/www.antikorupsi.org/mod=tema \&op=vie wartic le\&artid=53
} 
Republic of Indonesia Number 3209) on Criminal Procedure Code (hereinafter referred to as the Criminal Procedure Code), legitimate evidence includes:

a. Witness statements

b. Expert description

c. Letter

d. Hints

e. Defendant's description

Article 1 number 26 of Criminal Procedure Code states that:

"Witness is a person who can provide information for the sake of investigation, prosecution and judgment on a criminal case that he hears himself, he sees it himself and his own experience"

It is also mentioned in Article 1 number 27 of the Criminal Procedure Code:

"Testimony of witness is one of evidences in a criminal case in the form of testimony from witness regarding criminal incident he heard himself, he sees himself and he experiences himself by calling the reason of his knowledge."

Related to journalistic activities conducted by a journalist, journalist profession allows them to be witness.

Journalistic activities includes fining information or news that will certainly deal directly with an action or activity of others as source of the news. These activities will certainly be processed and submitted to the society. Transmission of the news will certainly provide a different response to the audience News in this society. This varied response will then lead to problems in the future both positive and negative.

However, in doing journalism activities, journalists especially in the process of finding sometimes receive inhumane treatment from the news sources. Such treatment can be in the form of blasphemy or destruction or beating (physical). In this case journalist acts as a victim of a criminal act committed by a news source. 
Kemerdekaan pers adalah kemerdekaan yang disertai kesadaran akan pentingnya penegakan supremasi hukum yang dilaksanakan oleh pengadilan, dan tanggung jawab profesi yang dijabarkan dalam Kode Etik Jurnalistik serta sesuai dengan hati nurani insan pers.

This is where the role of law to provide protection for the press in conducting journalistic activities. In Article 4 of the Press Law mentioned:

"Press freedom is guaranteed as a citizen's right"

It means that press is free from prevention, prohibition, and or suppressing measures that the right of the people to obtain information is assured. Freedom of press is an independence accompanied by awareness of the importance of law enforcement supremacy carried out by the courts and professional responsibilities described in Journalistic Code of Ethics and in accordance with the conscience of press.

Legal protection is required in the form of guarantee of protection from Government and or public for journalists in performing their functions, rights, obligations and roles in accordance with applicable laws and regulations.

The development of criminology and criminal law studies and practice of criminal justice systems has undergone considerable changes over the past few decades, particularly with regard to experts, academics and practitioners attention to the position of victims in criminal justice process.

The increasing concern for victim position in criminal justice is demonstrated by the production of various legal rules at both international and national levels, which regulate issue of protection and guarantee of the rights of victims.

In Indonesia attention to the position of victims in criminal justice system is more obvious with the enactment of Law of the Republic of Indonesia no. 13 of 2006 (State Gazette of the Republic of Indonesia of 2006 Number 64, Supplement to the State Gazette of the Republic of Indonesia Number 4635) on the Protection 
of Witnesses and Victims (hereinafter referred to as the Witness and Victim Protection Act).

In the Act, there are three points that become the main content:

1. Formulation of rights and forms of protection afforded to witnesses and victims;

2. Institutional Aspect of Witness and Victim Protection Agency (LPSK);

3. Provision of protection and assistance concerning aspects of the procedural mechanism of work of Witness and Victim Protection Agency (LPSK).

In the event that the position of the journalist either as a witness or victim of a criminal case automatically applies to it the Witness and Victim Protection Act. Having expressed the meaning of witness, in Witness and Victim Protection Act, victim is a person experiencing physical, mental and/or economic harm caused by a crime.

The definition of the victim is also mentioned in Government Regulation No. 2 of 2002 on Procedures of Protection to Witnesses and Victims of Serious Human Rights Violations, declaring that victim is an individual or a group of people who suffer as a result of heavy human rights violations that require physical protection and mental from threats, disturbances, terror, and violence from any party.

Definition of victims according to UN General Assembly Resolution No. 40/34 Year 1985 has broader scope, i.e victims are individuals, either individually or collectively, who suffer losses due to acts or do not act in violation of applicable criminal law in a country, including regulations that prohibit abuse of power. Harm according to UN General Assembly Resolution No. 40/34 Year 1985, includes physical or mental injury, emotional suffering, economic loss, or substantial impairment of fundamental rights. 
It further states that a person may be considered a victim regardless of whether the offender is known, detained, prosecuted or convicted and regardless of family relationship between perpetrator and victim. Victims also include close relatives or persons dependent on victims, as well as people who suffer losses for trying to prevent occurrence of casualties.

The following description is comparison of victim definition:

1. According to the PSK Act: A victim is a person who suffers physically, mentally, and/or economically caused by a crime.

2. According to Government Regulation No. 2 Year 2002: Victims are individuals or groups who suffer as a result of severe violations of human rights requiring physical and mental protection from threats, harassment, terror and violence from any party.

3. Declaration of Basic Principles of Justice for Victims: Victims are persons who, individually or collectively, have suffered harm, including physical or mental injury, emotional suffering, economic loss or substantial destruction of their fundamental rights, through acts or omissions contrary to applicable criminal law in member states, including laws that prohibit misuse of criminal power.

There is only one article for Right of witness protected in Criminal Code, this is Article 229. Thus, in practice it is disappointing in which right of witness to replace the cost after attending call in the judicial process cannot be fully implemented for classical reason of no funds.

Witness is victim in weak position. This can be seen in Criminal Code. In this case Criminal Code even threatens with criminal sanction if witness does not attend to provide information after receiving a call from law enforcement. Furthermore, the Criminal Criminal Code requires witness to swear and pledge 
prior to giving a statement with purpose that witness is able to provide genuine account of what is heard, seen, heard or experienced.

Obligations in law is closely related to Human Rights particularly right of witnesses, thus law gives right to witness in the form of protection for the witness.

In giving testimony, a witness bears the risk of his or her personal safety, family, and possessions, in addition to risks to jobs, occupations and careers. Therefore, protection of witnesses is not only protection of the law but also protection of personal safety, family and property. A witness does not gain any benefit, instead he takes risk. Witness and Victim Protection Act is created as a form of state or government accountability for the safety of its citizens. Witness and Victim Protection Act, everyone does not experience feelings of anxiety or fear when he/she is in a position as a witness or victim. Therefore, law enforcement against perpetrators of criminal acts can be truly enforced with a sense of justice.

\section{PROBLEMS}

In carrying out journalistic activities of searching, processing, storing and disseminating news to the public, journalists are sometimes faced with issues related to a criminal act committed by news sources.

Journalists may know very well about what happened, what has been experienced by news sources directly or indirectly. Various responses will be received by journalists on the news submitted. These responses can be either positive or negative (rejects) explicitly or in a hidden way. Upon a negative response a journalist is certainly in less unfavorable position.

Negative response may appear in responding report of journalists either through electronic media (such as television, radio, etc.) or through printed media (such 
as newspapers, magazines, etc.). This is what sometimes leads to a significant problem for journalists in performing their duties.

1. Can journalists become witnesses or victims in a legal process for a criminal case?

2.What forms of protection are provided by Witness and Victim Protection Act to journalists as witnesses or victims?

These problems frequently arise in the minds of society and become a question that needs to be answered so as to provide a correct understanding for the public, especially for journalists. This paper provides new knowledge on journalism that journalists can be more careful in doing journalism activities especially related to correct information to be delivered to the community.

\section{DISCUSSION}

In this paper, some issues described in the previous chapter will be discussed. These problems frequently arise in journalistic activities conducted by journalists. This problem often poses a threat to safety $s$ in journalistic activities.

1. Can journalists become witnesses or victims in a legal process for a criminal case?

In a criminal case, law enforcers sometimes seek and find clarity about a criminal act and find difficulties as he/she cannot bring witnesses or victims due to a threat. Therefore, it is necessary to provide protection for witnesses and/or victims as it is very important in the process of criminal justice.

In Criminal Code, witness is one of the few legal evidences under Article 184 (1) of Criminal Code which includes:

1. Description of witness

2. Description of Expert

3. Letter 


\section{Hints}

\section{Defendant's description}

The provision indicates that testimony of witness is one of the evidence arranged limitative in manner in Criminal Code that witness about a criminal event that he heard, he saw and he experienced by himself by mentioning the reason and his knowledge. However, the right of a witness in present law is still perceived low, as protection of witnesses and victims is still questionable.

Empowerment of a witness starts from the level of investigation, which then continues until the trial is held. Various threats both mentally and physically will always be present along with the involvement of various parties with the cases examined. This should receive attention to the development of law which requires a witness in the case of the disclosure of a case.

Many recent legal facts can serve as examples of how a witness is needed to reveal a criminal act. This is often the case for frightening witnesses who report a criminal case by reporting witnesses back to the police with allegations of defamation, slander, displeasure.

In addition, witness occasional receives physical violent attempts such as attempts of murder, torture, terror and psychological intimidation that the witness does not disclose the facts he/she knows.

Knowing the important the position and role of witnesses in the disclosure of truth in criminal cases, witnesses and reporters should receive legal, physical and psychological protection. Protection of witnesses in the Criminal justice process in Indonesia has not been clearly regulated in Criminal Code which only regulates the protection of suspects or defendants from various possibilities of human rights violations.

This makes witnesses reluctant to give testimony before the court. Sometimes he/she does not confess that he knows, sees criminal act, but on the contrary 
he is actually a key witness who can explain the criminal acts that occurred, especially in big cases involving officials, conglomerates. This happens as there is no protection against witnesses, their security will be threatened.

Protection of witnesses is currently urgent at every examination level in cases deemed to require special attention. Based on this Witness and Victim Protection Act was established as reference and guidance for law enforcement officer.

Menurut Pasal 1 angka 1 Undang-Undang Perlindungan Saksi dan Korban, saksi adalah orang yang dapat memberikan keterangan guna kepentingan penyidikan, penuntutan (peradilan) tentang suatu perkara pidana yang ia dengar sendiri, ia lihat sendiri dan ia alami sendiri.

According to the definition as mentioned in Criminal Code and Witness and Victim Protection Act, anyone can be a witness and give testimony regardless of the person's status including the suspect or the defendant. It also includes journalists as Indonesian Citizen. A journalist may serve as a witness in a criminal case as long as the journalist hears, sees and/or experiences a criminal act himself.

There is no prohibition against a suspect or a defendant to be a witness to a case that everyone is entitled to witness by criteria that he or she sees, hears and/or experiences himself. However, there are limitations as provided for in Article 168 of Criminal Code which specifies who is not able to be heard of his statements or may step down to be a witness:

1. Family, brother or and straight line up or down to third degree from defendant or jointly as defendant.

2. Brothers of defendants or co-defendants, siblings, mothers or fathers, as well as those who have a marriage relationship and children up to the third degree. 
3. Husband or wife of defendant even though he or she is divorced or together as the defendant due to familial relationship both siblings is also determined in Article 170 of Criminal Code for due to work, dignity or occupation is required to keep Secrets may request to be exempt from the obligation to give testimony as witnesses.

The explanation of the article is that occupation that determines the existence of the obligation to keep a secret is determined by laws and regulations ${ }^{10}$. Types of witnesses are:

\section{Witness of Crown}

Witness of crown is due to lack or absence of witnesses in the case, in this situation usually the witnesses are suspects or defendants. In practice, this is carried out in cases includes many suspects where the perpetrator consists of several people that there is a link between the defendant with each other ${ }^{11}$.

\section{Witness of Victim}

Victim can act as a witness to what he/she sees, hears or experiences on a criminal act which causes suffering or harm to him/herself. The victim is placed in a witness position that gives testimony as well as a central position for the litigants. In this sense, journalist can be positioned as a victim witness of a criminal case as journalists in doing journalistic activities directly see, hear or experience criminal act.

\section{Reporting Witness}

A reporting witness is a witness who reports on the occurrence of a criminal act because of rights or obligations under the Act as he or she has seen or heard. Witnesses are witnesses who come from people who are both interested or not interested toward the case, sometimes this witness receives praise but often a threat.

\footnotetext{
${ }^{10}$ Andi Hamzah,Pengantar Hukum Acara Pidana Indonesia, Sinar Grafika, Jakarta, 2005, p.239

${ }^{11}$ Rusdihardjo, Nilai Pembuktian Keterangan Saksi Mahkota Dalam Penyelesaian Perkara Pidana, Mabes POLRI, Jakarta, 1996, p. 14
} 


\section{Expert Witness}

Expert evidence is one of evidences as set forth in Article 184 of Criminal Code. Expert information is in the form of information given by a person who has special expertise about the things needed to enlighten criminal case for the purpose of examination. Thus, an expert testifies on the basis of his expertise and experience of a particular matter.

1. What forms of protection are provided by Witness and Victim Protection Act to journalists as witnesses or victims?

Student-led reform movement has resulted in a new phenomenon at 53 years of independence of the Republic of Indonesia, which requires a total reform that covers the political, economic and legal fields. According to A. Muis, reformation era should be given meaning as re-actualization of nature of proclamation of independence of this nation that failed to be implemented by New Order in the form of limitation on freedom of opinion, sovereignty of the people, respect for human dignity (Human Rights) and recog nition of civil society.

The failure of New Order to implement its own objective of implementing the 1945 Constitution of the Republic of Indonesia and Pancasila in a pure and consequent manner, has brought great disaster to the Indonesia. For more than 30 years the rights of the community have been locked up ${ }^{12}$. One of the rights of the dependent community is the rights of witnesses in the criminal justice process.

State of Law can be distinguished into 2 (two) characteristics from aspect of formal law and material law. In addition, the characteristic of formal legal state according to Friederich J Stahl as quoted by Moch Mahfud MD are:

1. Human rights.

\footnotetext{
12 Nyoman Serikat Putra Jaya, Sistem Peradilan Pidana (Criminal Justice Sistem), (Bahan Kuliah Program Magister Ilmu Hu ku m Universitas Diponegoro,Semarang: 2006), p. 5.
} 
2. Separation or division of power to guarantee the human rights commonly known as Trias Politica.

3. Government based on regulations

4. Justice administration in dispute ${ }^{13}$.

Indonesia as a state of law also needs to understand condition of world that has paid bigger attention to human rights as in reform era a big agenda requires a change of life order in nation and state. One of the most notable changes is the protection of citizen rights related to Human Rights. In Indonesia today there are various bodies that partially handle legal protection for the people. Rochmat Soemitro groups them into three bodies:

a. Courts within the General Courts (abbreviated to the General Courts). It is generally used in violation of public law.

b. Government agencies which are administrative appeals agencies

Law protection for the people through the government agency means an agency appeal administration is an appeal against an act of government by those who feel aggrieved by such measures to the government officials who are hierarchically higher or to a government official ${ }^{14}$.

c. Special agencies ${ }^{15}$

For example the State Administrative Court

In the protection of human rights there has been a great deal of protection that have been clearly and firmly stipulated in legislation such as those set forth in child protection legislation, protection of women, domestic violence, only witness protection is almost forgotten on reform agenda. This proves that there is a discrimination in the protection of law, especially by looking at emergence process of the Witness Protection Act itself which was delayed for five years.

\footnotetext{
${ }^{13}$ Moch Mahfud MD, Hukum dan Pilar-pilar Demokrasi, Gama Media, Yogyakarta, 1999, p. 127.

${ }^{14}$ Philipus M Hadjon, Loc. Cit, p. 12

${ }^{15}$ Roch mat Soe mitro, Loc. Cit, h. 44
} 
The fulfillment of the right to a sense of security in order to protect witnesses and victims in a criminal case becomes an essential requirement for the legal proceedings in court to proceed. Witnesses is parties having their own knowledge based on what they experienced, seen, and/or heard of in relation to the alleged occurrence of a crime. Based on the definition, it is possible that witness is also the victim or the aggrieved party of the event.

Witness is expected to explain the sequence of events related to an event that becomes an object of examination before the trial. Witnesses with other evidence, will assist judge to impose fair and objective judgments based on legal facts revealed.

The success of a judicial process depends highly on the evidences that have been successfully revealed at the court level, especially with regard to witness. From standpoint of legislation, the position of the witness including victim is in weak position. Criminal Code, for example, even threatens with criminal, witnesses who do not come when law enforcement asks them to give testimony.

Comparing legal protection of witnesses and defendant, is defendant's rights given because of his weak position and abuse of power? Witness is citizen and victim whose interests are harmed, as it has been represented by the state acting as the executor of the legal process, it is considered that rights providing protection for witness in judicial process is unnecessary. In fact, witness is not much different from suspect/defendant, they both need protection.

In fact, most witnesses are unwilling to give testimony in the hearing which is similar to defendant. Becoming witness in trial is perceived "scary" that witness will think twice to testify. Although theoretically, witnesses, especially victim witnesses have been represented by law enforcement agencies, in reality they are only used as legal tools to support, strengthen the argument to win the 
case. The victory of the law enforcement apparatus, with his success proving the defendant's wrongdoing and convincing the judge about it, is in fact a victory of the community (including the victim).

Occasionally law enforcement officers ignore party they represent. Whether the victim is satisfied with the prosecutor's demands or the judge's verdict, for example, is something that is rarely noticed. The manifestation of society's discontent with the treatment of the representatives, then appears in various forms from shoe throwing to judges, court building destruction, to occasional vigilante action which sometimes occurs. Action of anarchy by the society stem from feelings of dissatisfaction, feelings of being treated unfairly in society.

At the time of giving testimony, witness must be able to give correct information. To that end, witness needs to feel safe and free when examined in front of the trial. He/she should not hesitate to explain the actual event, although perhaps his statement is incriminating the defendant. Thus, in Criminal Code, it is authorized to the Panel of Judges to enable a witness to hear his testimony without the presence of the defendant.

The reason is to accommodate the interests of witness that he can speak and give his information more freely without fear, worry or distress. Witness must also be freed from fear, worried about the impact of the information given. A person may refuse to testify, or if he is forced to lie as he will not risk his life or the life of his family because of his accusation against the defendant. On the other hand, a person refuses to give testimony because of the trauma of a criminal event that he does not have the ability to retell the events he experienced.

Some cases cannot be brought to trial or stopped in the middle of the road because of this one issue. Cases such as serious violations of human rights violations, corruption or narcotics crimes involving a syndicate, or cases 
of gender-based violence are examples of cases frequently unprocessable as no witnesses are willing and daring to provide true information.

This leads to failure of fair, honest and authoritative judicial process to fulfill a sense of justice and violation of the individual rights involved in the case.

There have been laws that explicitly regulate protection of witnesses and victims in Indonesia under the Law No.13 of 2006 on Protection of Witnesses and Victims. In addition, such protection is also implicitly regulated in several Laws such as Criminal Procedure Code, Corruption Eradication Act, Law on Protection of Human Rights.

Such protection shall be provided to any person or citizen who is both a witness and a victim in a criminal case. Protection should be also given to journalists if for some reason work, he becomes a witness or victim of a criminal process.

Witness is not much different from suspect or defendant. They both need protection for their own safety for the following reasons:

1. For witness (especially those who do not understand about law), giving information is not an easy thing.

2. If the information provided is not true, there is a criminal penalty for him/her because of his perjury.

3. The information given will enable him to be threatened, terrorized, intimidated by the injured party.

4. Providing information is wasting time and money.

5. Law enforcement officials frequently treat witnesses like a suspect or a defendant. 
There must be a dilemma for witnesses. On one hand he must fulfill the but on the other hand his own rights are not fulfilled and even disadvantaged by the interests of examination in every criminal justice process.

The harm suffered by a witness is a right violated by law. Not only the problem is on fee but also threats both physically and mentally, under these circumstances witnesses sometimes object to provide testimony in the criminal justice process.

Criminologists today do not only devote their attention to criminals; they begin to notice other parties besides criminals, especially victims of crime as those harmed by a crime. The role of victims in criminal justice system is crucial in terms of evidence, since victims often have the quality of being witnesses (witnesses of victims) in addition to other witnesses as legal evidence in criminal proceedings ${ }^{16}$.

The need for legal arrangement and protection for victim witnesses can be sociologically justified that in social life all citizens must participate fully as society is seen as a system of institutionalized trust. Without this belief it is impossible for social life to run well as there is no definite benchmark in behaving. This belief is integrated through norms expressed in organizational structures such as police, prosecutors, courts and so on.

Law as a norm of society has characteristics of the specificity to protect, regulate and provide balance in keeping public interest. Law as a norm has the following functions ${ }^{17}$ :

1. Law that guarantees legal certainty

2. Law that ensures social justice

3. Law functions in a protection ${ }^{18}$

\footnotetext{
${ }^{16}$ Nyo man Serikat Putra Jaya, Op Cit, p. 51

${ }_{17}$ Abdoel Djamali, Pengantar Hukum Indonesia, Raja Grafindo Persada, Jakarta, 1993, p. 3

${ }^{18}$ Bachsan Mustafa, Sistem Hukum Indonesia Terpadu, Citra Aditya Bakti, Bandung, 2003, p. 20
} 
Each legal provision functions to achieve order of interpersonal relations in social life. Law preserving unity of life avoids psychological and physical imbalance in social in the presence of pressure or inappropriateness of social ties.

This means also to maintain justice in social life (society). Norm of law is something that concerns human life within certain social groups, both in situations of togetherness and social situations to achieve order for justice ${ }^{19}$.

This also applies to victims of crime. With the occurrence of crimes against him it will destroy that belief. In this case, regulation of criminal law and others serves to restore the trust.

Based on the idea that community life is the institutionalized belief system, the emergence of demand to pay attention to the fate of victim is acceptable. According Muladi, in the framework of the concept of regulation of victims of crime, the first thing to note is the essence of the losses suffered by the victim. The essence of loss is not only material or physical suffering but also psychological. It is in the form of trauma, loss of confidence in society and public order. Simton and the syndrome can be anxiety, suspicion, cynicism, depression, loneliness and other avoidance behaviors ${ }^{20}$.

Muladi states that the need for legal arrangement and protection for witnesses and victims can be sociologically justified that in social life all citizens must participate fully as society is seen as a system of trust institutionalized "system of in instuitutionalizet trust". Without this belief, social life can not work well as there are no definite guidelines or standards in behavior. This belief is integrated through norms expressed within institutional structures

\footnotetext{
${ }_{19}$ Abdoel Djamali, Op. Cit

${ }^{20}$ Muladi, Hak Asasi Manusia, Politik dan Sistem Peradilan Pidana, Badan Penerbit Universitas Diponegoro, Semarang, 2002, p. 176
} 
(organizations) such as police, prosecutors, courts, corrective bodies and so $\mathrm{on}^{21}$.

In principle, the protection of rights of a person as a witness has been accommodated in Criminal Code. However, the increasingly diverse types of criminal acts which have an effect on the safety of witness or the victim or his family, there are special matters set forth in Article 5 of Witness and Victim Protection Act

In the Law on Protection of Witnesses and Victims some form of protection granted and guaranteed by the state. Article 5 Paragraph (1) of Witness and Victim Protection Act states that a witness and a victim has the right::

A. Obtain protection for personal, family and property security nd free from threats related to testimony that will, or have been given. This kind of protection is the primary protection required by witnesses and victims. Where appropriate, witnesses and victims shall be placed in an undisclosed location from anyone to ensure that witnesses and victims are safe.

B. Participate in the process of selecting and determining the form of protection and security support. Witnesses and victims have the right to actively participate in determining forms of protection for themselves.

C. Providing information without pressure

Witnesses and victims have the right to be able to give information freely, securely, and without pressure from any party.

D. Obtaining translator

This right is given to witnesses and victims who are not fluent in Bahasa Indonesia to facilitate the proceedings.

E. Free from trap questions

${ }^{21} \mathrm{Ibid}$, h. 175 
Witnesses and victims are entitled not to have any questions that may preclude witnesses and victims themselves in criminal act.

F. Obtaining information on case progress

Often witnesses and victims are only instrument in giving testimony before the court. However, these witnesses and victims are not aware of the progress of the case. Therefore, information on the progress of the case should be given to witness and victim.

G. Obtaining information on court decisions

This information is important to be known by witnesses and victims as appreciation for the willingness of witnesses and victims in the smoothness of the judicial process.

H. Knowing that defendant is released.

The fear of witness and the victim for the act of retaliation from the defendant is reasonable, thus, witness and the victim are entitled to be informed if a convicted person who has served a prison sentence will be released. Prudent actions will be taken by witnesses and victims.

I. Obtaining a new identity

In many cases, especially with regard to organized crime, witnesses and victims may be at risk of their safety even if the accused has been punished. Therefore, in certain cases witnesses and victims can be given a new identity.

J. Obtaining new residence

If the security of witnesses and victims is considered to be severely worrying, giving new places to witnesses and victims should be considered. This is necessary that witnesses and victims can continue their lives without fear. "new residence" is a certain place that is temporary and considered safe.

K. Obtain replacement of transportation cost as needed. 
Witnesses and victims who are unable to finance themselves to visit the site need to receive assistance provided by the state. It is endeavored that witness and the victim can feel calm, not distressed in their efforts to give information.

L. Obtaining legal advice

the legal advice is required by witnesses and victims when necessary as in general witness and the victim do not understand law.

Provide temporary living expenses until protection ends.

"temporary living expenses" is the cost of living that is appropriate to the situation at the time, such as the cost of daily meals. This is for example because the witness and the victim cannot work because they have to give information either in the process of investigation to the court process or at the court.

Protection and right of witnesses and victims shall be granted since the investigation stage to the end in accordance with the provisions of the law. In fact, in giving testimony before the court, if their presence is threatened, Law should provide protection to witnesses or victims or the family by allowing testimony without presence before the trial.

Witness and Victim Protection Act provides protection and assistance to witnesses and victims. Protection is in the form of deeds that provide shelter or protection as needed for security. Witness and Victim Protection Act divides procedures for protecting and providing assistance differently. Protection is the rights granted in accordance with Article 5 of Witness and Victim Protection Act mentioned above.

Assistance is provided in Article 6 of Law on Protection of Witnesses and Victims in this case Victims face severe violations of Human Rights. In addition to the rights referred to in Article 5 of Witness and Victim Protection Act, 
witnesses and victims are also entitled to receive medical assistance and psycho-social rehabilitation assistance.

Protection mechanisms is set forth in Article 18 of Witness and Victim Protection Law which require application of protection by witnesses/victims on their own initiative or by the authority, and the decision on protection is given in writing by Witness and Victim Protection Agency (LPSK) maximum (7) seven working days after the application for protection is submitted. Submission should be made by a parent or guardian against a victim or a witness still under age or children.

Article 28 of Witness and Victim Protection Act provides provision of protection and assistance with regard to terms of provision of protection and assistance, threat levels that endanger witnesses and victims, the results of the medical team or psychologist's analysis of witnesses and/or victim.

In addition Article 29 of Witness and Victim Protection Act provides for witness and/or victims weither on his own initiative or by request of the competent authority. Article 30 of the Witness and Victim Protection Act is further regulated in the event that Witness and Victim Protection Agency receives the request of witnesses and/or victims. As referred to in Article 29 of Witness and Victim Protection Act, witnesses and/or victims sign a statement of willingness to comply with the terms and conditions.

The requirements contains willingness of witness and or victim to testify in judicial process, willingness of the witness or victim to comply with rules related to his or her safety, willing ness of witness and/or the victim to anyone other than consent of the Witness and Victim Protection Agency while he is under protection Witness and Victim Protection Agency.

Protection of witness and victim's safety may be terminated on the grounds of witness and or victim's request, for request of the competent authority as witness or victim violates the provisions of agreement or Witness and Victim 
Protection Agency and/or victims no longer requires protection based on convincing evidence and suspension of security protection of a witness and or victim in writing form.

\section{CONCLUSION}

Referring to Witness and Victim Protection Act, Criminal Code, etc., the following conclusions is drawn:

1. Journalist as journalistic perpetrator can be categorized as a witness or victim if the condition fulfills the requirement as witness or victim as mentioned in Law of Witness and Victim Protection, Criminal Code. Victim means journalist is suffering from physical, mental, and/or economic loss caused by criminal act and as a witness if the reporter hears on his own behalf and personally experiences a criminal act.

2. As a witness and victim, journalist is also entitled to the protection of the law granted by the state as in Witness and Victim Protection Act. These rights ensure safety and security of witnesses and victims to assist smoothness in a criminal proceeding process

3. The forms of protection afforded to witnesses and victims under Witness and Victim Protection Act can be categorized as follows:

\section{A. Physical and psychological protection}

Security and escort, safe house placement, new identity, medical assistance and testimony without being directly present in court, psycho-social rehabilitation assistance.

\section{B. Legal protection}

The relief of punishment, as well as witnesses and victims and complainants can not be prosecuted.

C. Fulfillment of procedural rights of witnesses 
Assistance, interpretation, information on case progress, reimbursement of transportation costs, legal advice, temporary living expenses up to the time limit of protection.

\section{BLIBIOGRAPHY}

Burg, F.H. van der, (1983) Rechtsbescherming tegen de Overheid, serie, Staats-en Bestuursrecht 1, Nijmegen.

Djamali, Abdoel, (1993) Pengantar Hukum Indonesia, Raja Grafindo Persada, Jakarta.

Hadjon, Philipus M. (1987) Perlindungan Hukum Bagi Rakyat Indonesia, Bina Ilmu, Surabaya.

Hamzah, Andi, (2005) Pengantar Hukum Acara Pidana Indonesia, Sinar Grafika, Jakarta.

Jaya, Nyoman Serikat PutraJaya, (2006) Sistem Peradilan Pidana (Criminal Justice Sistem), (Bahan Kuliah Program Magister Ilmu Hukum Universitas Diponegoro), Semarang.

Mahfud, Moch, (1999) Hukum dan Pilar-pilar Demokrasi , Gama Media, Yogyakarta.

Moeljatno, (1987) Azaz-Azaz Hukum Pidana, Bina Aksara, Jakarta.

Muladi, (2002) Hak Asasi Manusia, Politik dan Sistem Peradilan Pidana, Badan Penerbit Universitas Diponegoro, Semarang,

Mustafa, Bachsan, (2003) Sistem Hukum Indonesia Terpadu, Citra Aditya Bakti, Bandung.

Rusdihardjo, (1996) Nilai Pembuktian Keterangan Saksi Mahkota Dalam Penyelesaian Perkara Pidana, Mabes POLRI, Jakarta.

Soemitro, Rochmat, (1976) Masalah Peradilan Administrasi Dalam Hukum Pajak di Indonesia, Eresco, Bandung. 
Suhandang, Kustadi, (2010) Pengantar Jurnalistik Seputar Organisasi, Produk \& Kode Etik, Nuansa, Bandung.

Susanto, Astrid S., (1986) Komunikasi Massa, Bina Cipta, Bandung.

INTERNET

Fitriasih, Surastini, "Perlindungan Saksi Dan Korban Sebagai sarana Menuju Proses Peardilan (Pidana) Yang Jujur Dan Adil", http/www.antikorupsi.org/mod=tema\&op=viewarticle\&artid=53 